\title{
Obstetric Violence and Medical Education
}

\section{Dear editor,}

The timing was very opportune on the authors, Nathalia M. Klering, Laura R. Petry, Henrique Garzella, Karolyn Sassi Ogliari and Juliana N. Scherer's proposal regarding the need to transform professional health education, as well as the established relationship in the context of women's healthcare.

Obstetric violence is a complex and multifactorial phenomenon, which is established in three interchangeable and symbiotic spheres, namely: within the individual, institutional and structural context. 1 Individual violence - abundantly documented by women's reports that cannot be ignored 2,3 - is supported by an institutional level of standardized and imposition of invasive and unnecessary procedures. This institutional violence, is socially and historically constructed, reflecting - and composing - an oppressive and violent structure, which pathologizes the female body and the process of childbirth and birth. 4,5

In this context, we agree with the authors' letter about the centrality of the curricula in health courses in this process. We are taking this opportunity to emphasize that there is no neutral position when we mention about structural violence. ${ }^{1}$

Since silence is contingent on the enunciator, ${ }^{6}$ by quietening about Obstetric Violence, the academic curricula condone the perpetuation of power relation that subjugate women's bodies and undermine their autonomy. By using the concept of Evidence-Based Medicine (EBM) in an abstract way, the academy contributes in educating professionals who are unable to recognize good evidence and ignores the shared decision-making as one of its pillars. ${ }^{7}$ Whilst, by approaching the concept of Humanization in a shallow and reduced way, disregarding its histo-rical construction, its inappropriate use is encou-raging.

The so-called "humanization" appeared from a movement of reviews of moral and attitudinal values emerging from Modernity 8 and strengthened in the $19^{\text {th }}$ and early $20^{\text {th }}$ centuries. The belief in the supremacy of pure reason and the overvaluation of individualism culminated in quite destructive and violent events, ${ }^{9}$ including in the healthcare area. 10 As a counterpoint, in the second half of the 20th century, there were movements to contest this reality, such as Human Rights, Bioethics and Humanization. 8,11 The emergence of EBM, has strengthened these movements by exposing the pitfalls associated with intervention $t$ and violent forms in care. In the case of childbirth care, EBM rewrites childbirth as a physiological process, in addition to being violent, the interventions denounced by the humanization movements were less effective and potentially harmful. 12

Ttherefore, the health humanization, should not be confused with charity or concession. On the contrary, this movement aims for a care model guided by ethical and respectful interpersonal interactions, among professionals and the people they care for, in addition to demanding better working conditions and an adequate environment for care practices. 13

Therefore, we reinforce the authors' perception of the letter in response to our article, agreeing with the urgent need for a profound curricular reform in 
the Medical Education. We definitely need to abandon dichotomies that still anchor medical practices in archaic ideals, which contribute to sustain structural violence. We need to reform the curricular and standardize practices that best combine scientific humanities, and bioethics evidences since these are intertwined and necessary concepts to consolidate an effective and socially constructed medical practice.

\section{Authors' contribution}

All authors fully participated in the construction of this manuscript and approved the final version.
Aline Veras Brilhante 1

iD https://orcid.org/0000-0002-3925-4898

Maria Helena Bastos 2

iD https://orcid.org/0000-0002-1001-1083

Juliana Camargo Giordano 3

iD https://orcid.org/0000-0002-3773-7597
Leila Katz 4

iD https://orcid.org/0000-0001-9854-7917

Melania Maria Amorim 5

iD https://orcid.org/0000-0003-1047-2514

1 M1 Universidade de Fortaleza. Fortaleza, CE, Brasil.

2 UK Cochrane Centre. Oxford, Oxfordshire.

3 Instituto Gerar. São Paulo, SP, Brasil.

4,5 Instituto de Medicina Integral Prof. Fernando Figueira. Rua dos Coelhos, 300. Boa Vista. Recife, PE, Brasil. CEP: 50.070-902. E-mail:katzleila@gmail.com

\section{References}

1. Sadler M, Santos MJ, Ruiz-Berdún D, Rojas GL, Skoko E Gillen $\mathrm{P}$, et al. Moving beyond disrespect and abuse addressing the structural dimensions of obstetric violence. Reprod Health Matters. 2016; 24 (47): 47-55.

2. Niles PM, Stoll K, Wang JJ, Black S, Vedam S. "I fought my entire way": Experiences of declining maternity care services in British Columbia. Ameh CA, editor. PLOS ONE. 2021; 16 (6): e0252645.

3. Ciello C, Carvalho C, Kondo C, Delage D, Niy D, Werne L, et al. Violência Obstétrica "Parirás com dor" Dossiê elaborado pela Rede Parto do Princípio para a CPMI da Violência Contra as Mulheres. Brasília, DF; 2012 [cited 2021 Jun 23]. Available from: http://www.senado.gov.br/ comissoes/documentos/SSCEPI/DOC\%20VCM\%20367.pd $\mathrm{f}$

4. Aronson J, Burgess D, Phelan SM, Juarez L. Unhealthy interactions: The role of stereotype threat in health disparities. Am J Public Health. 2013; 103 (1): 50-6.

5. Salter CL, Olaniyan A, Mendez DD, Chang JC. Naming Silence and Inadequate Obstetric Care as ObstetricViolence is a Necessary Step for Change. Violence Against Women. 2021; 27 (8): 1019-27.

Received on June 30, 2021

Final version presented on July 6, 2021

Approved on July 15, 2021
6. Orlandi EP. A leitura e os leitores possíveis. In: A Leitura e os Leitores. Campinas: Pontes; 1998. p. 7-24.

7. Djulbegovic B, Guyatt GH. Progress in evidence-based medicine: a quarter century on. Lancet. 2017; 390 (10092): 415-23.

8. Rios IC. Humanização: a essência da ação técnica e ética nas práticas de saúde. Rev Bras Educ Méd. 2009; 33 (2): 253-61.

9. Bauman Z. Modernidade e ambivalência. Rio de Janeiro: Jorge Zahar Ed.; 1999

10. Silva Souza W, Moreira MCN. The topic of humanization with in healthcare: Some issues for debate. Interface: Communication, Health, Education. 2008; 12 (25): 327-38.

11. Rego S, Gomes AP, Siqueira-Batista R. Bioética e humanização como temas transversais na formação médica. Rev Bras Educ Méd. 2008; 32 (4): 482-91.

12. Rossignol M, Chaillet N, Boughrassa F, Moutquin JM. InterrelationsBetween

Four AntepartumObstetricInterventionsandCesarean Delivery in WomenatLow Risk: A Systematic Review and Modeling of the Cascade of Interventions. Birth. 2014; 41 (1): 70-8.

13. Benevides R, Passos E. A humanização como dimensão pública das políticas de saúde. Ciênc Saúde Coletiva. 2005; 10 (3): $561-71$ 


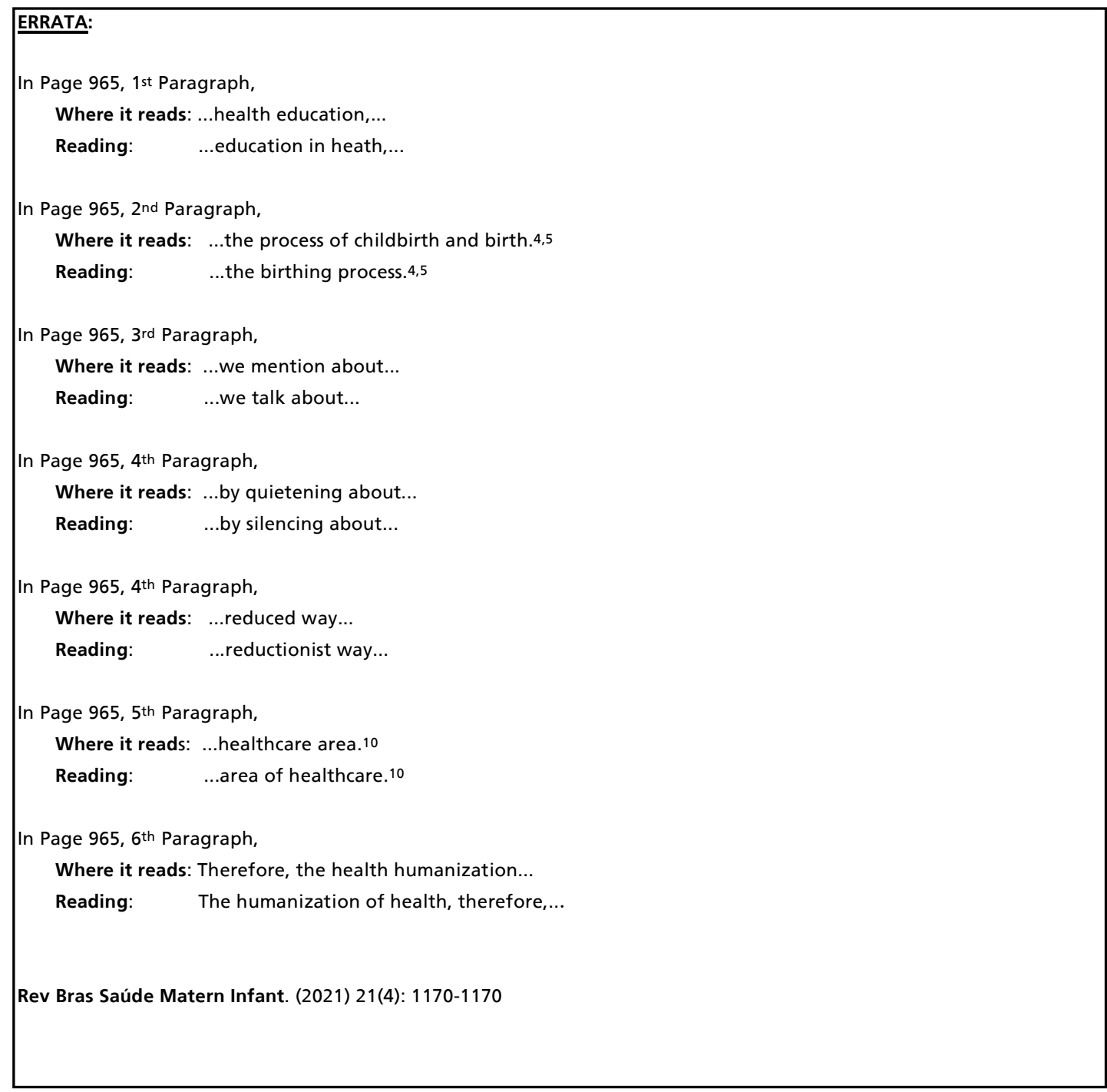

